\title{
İSLAM GELENEĞİ AÇISINDAN KUDÜS
}

\author{
Kudüs, sen diğer yerlerden benim daha \\ sevdiğim bir yersin. Mümin kullarımdan sevdikle- \\ rimi sana gönderirim. Kudüs sen benim nurumla \\ nurlanmışsın. Seni ziyaret eden kişi ne mutludur, \\ sonra cennet sendedir, azabim sendedir. ${ }^{1}$
}

Rabia MERT *

\section{Özet:}

İslam geleneğinde Kudüs'ün ifade ettiği anlam ve önem bu makalenin konusunu oluşturmaktadır. Makalede Kudüs'ün Müslümanlar için tarihi ve dini olarak neden önemli olduğunun belirtilmesi amaçlanmıştır. Bu sebeple çalışmada Müslüman geleneğindeki Kudüs ile ilgili anlatılar şehrin Müslüman egemenliğinde bulunduğu tarihi dönemlerle birlikte ele alınmıştır. Çalışmada deskriptif ve fenomenolojik metot kullanılmıştır. Tarihi ve dini kaynaklarda şehirle ilgili yer alan bilgiler toplanarak konu açıklanmıştır. Kudüs’ün Müslüman tarihindeki yeri Hz. Peygamber'in ilk kıble olarak oraya yönelmesiyle başlar, Hz. Ömer dönemindeki fetihle de yeni bir ivme kazanır. Bundan sonra da arada geçen bir asırlık Haçlı dönemi hariç tutulursa şehir, Birinci Dünya Savaşı sonrasına kadar yaklaşık 14 asır Müslümanların idaresinde kalmıştır. Kudüs, Müslümanlar için Mekke ve Medine’den sonra üçüncü önemli kutsal mekândır. Bu anlamı kıble, miraç hadiselerindeki rolü yanında hadislerde geçen ifadeler ve şehirle ilgili anlatılarda bulunmaktadır. Bahsedilen hususlar şehrin Müslümanlar için önemli olmasının sebeplerini oluşturmaktadır.

Anahtar Kelimeler: Kudüs, Mescid-i Aksa, Kubbetü’s-Sahra, Kıble, Miraç.

1 Muhammed Yemeni, Feza'ilü'l-Mekke ve'l-Medine ve'l-Kudüs, ty, y.y., s. 131; Buradaki ifadelerin Muaz tarafindan Rasulullah'tan rivayet edildiği ve kutsi hadis olduğu kabul edilmektedir.

* Arş.Gör.Dr., Sinop Üniversitesi İlahiyat Fakültesi, rabiamert@sinop.edu.tr 


\title{
Jerusalem, According to the Islamic Tradition
}

\begin{abstract}
:
The subject of this article is the meaning of Jerusalem and its importance in the Islamic tradition. It is aimed to explain why Jerusalem is important for Muslims of its historical and religious value in article. For this reason, it was taken together the accounts of the Muslim tradition about Jerusalem with those living historically in the Muslim dominance in the study. It is used descriptive and phenomenological methods in the study. It is explained subject that historical and religious sources gathered information about the city. Jerusalem's place in Muslim history begins with the Prophet who first direction to there as qibla with the conquest of Umar it gained a new impetus. Except for a century-old crusader period, the city remained in the Muslim administration for about 1400 years until First World War. Jerusalem is the third important holy place for Muslims after Mecca and Medina. This meaning can be found the role of the qibla, the miraculous, the expressions in the hadiths and in the stories about the city. These are the reasons why the city is important to Muslims.
\end{abstract}

Keywords: Jerusalem, Masjid al-Aqsa (al-Aqsa Mosque), Dome of the Rock, Qibla, Ascension.

\section{Giriş}

Kudüs şehrinin yaklaşık olarak MÖ 3000'lerde kurulduğu, ${ }^{2}$ MÖ 1800'lerde ise Hz. İbrahim'in bu bölgeye göç ettiği kabul edilmektedir. ${ }^{3}$ Yahudi geleneğinde Kudüs'e verilen önemin Avraam/İbrahim'in buraya gelişi ile başladığına inanılmaktadır. Nitekim Tevrat'ta İbrahim'in eşi Sara ve kardeşi Haran'ın oğlu Lut'u alarak Mezopotamya'dan Tanrı'dan aldığı emirle Kenan diyarına gelmesinden bahsedilmektedir. ${ }^{4} \mathrm{Bu}$ anlatı daha sonra vaat edilen toprak/arz-ı mevud olarak geliştirilmiş ve Yahudiliğin en bariz teması olarak ortaya çıkmıştır. Kral Davud'un Kudüs'ü fethetmesi ile vaat edilen toprakların merkezinin burası olduğu belirtilmiştir. Daha

2 Karen Armstrong, Jerusalem one city three faith, Ballantine Books, United States Of America 1996, s. 3.

3 Şemsettin Günaltay, Yakın şark, Suriye ve Filistin III, Türk Tarih Kurumu Yayınları, Ankara 1947, s. 53.

4 Tekvin, 12/1-5. 
sonra ise oğlu Süleyman tarafından Kudüs’teki Tapınak Tepesi/Moriah Dağı üzerine bir mabet (Süleyman Mabedi) inşa edilmesi ile burası kutsal bir mekân olarak öne çıkmıştır. ${ }^{5}$ MÖ 586' da ve MS 70 yılında iki defa Kudüs'ün harap edilmesi ve mabedin yıkılması da bu algıyı değiştirmemiştir. ${ }^{6}$ Hıristiyanlığın ortaya çıkışından sonra burası İsa Mesih ile olan bağlantısı sebebiyle önemini devam ettirmiştir. ${ }^{7}$ Kudüs, Hz. Muhammed'in hayatında yer alan kıble ve miraç hadiseleri dolayısıyla Müslümanlar için de kutsal bir mekândır. Kudüs'e Müslümanların atfettikleri anlam nedeniyle şehir, Hz. Ömer döneminde fethedilmiş ve 20. yüzyılın başlarına kadar Müslüman egemenliğinde kalmıştır.

\section{Müslüman Egemenliğinde Kudüs'ün Konumu}

Müslümanların Filistin bölgesindeki fetih hareketleri Hz. Ebubekir döneminde başlamıştır. Halid b. Velid'in 634 'te yaptığı Ecnadeyn savaşı neticesinde Müslümanlar Filistin kapılarına kadar gelmiştir. Şam fethi sırasında orada bulunan Hıristiyanlarla hayatlarının, mallarının ve kiliselerinin emniyette olduğunu belirten anlaşmalar imzalanmıştır. Bu anlaşmalar daha sonra Filistin bölgesi için de örnek olmuştur. Hz. Ömer Halife olduğunda Şam bölgesindeki Müslüman ordusunun genel komutanlığına Ebu Ubeyde'yi tayin etmiştir. O dönemde bölgenin idaresi Bizans yönetimine aittir. Bizans imparatoru Herakliyus, kardeşi Theodorus'un kumandasında Yermük vadisinde askeri kuvvetlerini toplamıştır. 636' da yapılan savaşta Müslüman ordusu galip gelmiştir. ${ }^{8}$ Yapılan savaştan sonra bölgedeki şehirlerin teslim alınmasına karşın Kudüs şehri bir süre daha kapılarını Müslümanlara kapalı tutmuştur. Ebu Ubeyde, Kudüs halkına bir mektup göndermiş ve şehrin teslim olmasını

5 II. Samuel, 5/6-7; I. Krallar, 6/1, 14; Flavius Josephus, The works of Josephus, (Trans. William Whiston), Hendrickson, America 1999, Antiquities of the jews, 8: 4: 1.

6 Ömer Faruk Harman, "Kudüs", Di், İstanbul 2002, c. XXVI, s. 325.

7 Armstrong, Jerusalem, s. 170-171.

8 Philip Khuri Hitti, Siyasal ve kültürel İslam tarihi, (Çev. Salih Tuğ), İFAV, İstanbul 2011, s. 214-216. 
istemiştir. Kudüs halkı Halifenin kendilerine gelmesi şartıyla teslim olacaklarını bildirmiştir. Bunun üzerine Hz. Ömer'in bu bölgeye geldiği bilinmektedir. ${ }^{9}$

Hz. Ömer, Cabiye bölgesine gelmiş ve burada komutanlarla görüşmüştür. Sonrasında Kudüs kalesinden Cabiye'ye gelen bir grup ile barış anlaşması yapılmıştır. Böylece Kudüs, 638 yılında Müslüman idaresine geçmiş oldu. Burada bulunan Hz. Ömer, Hıristiyan halkın can, mal ve din hürriyetini içeren bir eman yazmıştır. ${ }^{10}$ Buna göre:

- Kiliselerde oturulmayacak, kiliseler ile haçları ve malları yıkılmayacak, azaltılmayacaktır.

- Dinlerinden dolayı rahatsı edilmeyeceklerdir.

- İlya/Kudüs halkı diğer şehirler gibi cizye verecektir.

- İlya’yı terk eden birisi kendisi ve malı ile birlikte gideceği yere kadar emniyette olacaktır.

- İlya/Kudüs’te oturmak isteyen başka yerlerden gelen Hıristiyanlar da diğerleri gibi cizye ödeyecektir.

- Bunlardan ancak hasat zamanı vergi alınacaktır.

Kudüs'ün alınmasından sonra Hz. Ömer şehri ziyaret etmiştir. Bu ziyaret esnasında Kudüs patriği Sophronius, kutsal yerleri gezerken kendisine eşlik etmiştir. Hz. Peygamber'in miraca çıktığı mekânı görmek isteyen Halife, durumu Kab'ul Ahbar'a sormuş ve Cehennem Vadisi ile Sahra arası ölçülerek Mescid-i Aksa'nın yeri tespit edilmiştir. Halife ve yanındakiler Sahra kayasının bulunduğu yere geldiklerinde buranın çöplük olduğunu görmüşlerdir. Bunun sebebi ise Hıristiyanların Yahudilere olan nefretinden Süleyman Mabedi’nin yer aldığ 1 kısmı çöplüğe çevirmeleridir. Hz. Ömer ve yanındakiler tarafından temizlenen bu yere bir mescit inşa edilmiştir. ${ }^{11}$

9 Ebü'l-Fidâ İmâdüddin İsmâil b. Şihâbiddîn Ömer İbn Kesîr, el-Bidaye ve'n-nihaye, Beytü'l Efkarü'l Devliyye, Amman 2004, c. I, s. 1243-1244.

10 Mustafa Fayda, Hz. Ömer zamanında gayr-ı müslimler, Marmara Üniversitesi İlahiyat Fakültesi Yayınları, İstanbul 1989, s. 145-146.

11 Moudjir ed-Dyn, Histoire de Jerusalem et d'Hebron depuis Abraham jusqu'a a la fin du $X V$ siecle de j.c, (Trans. Henri Sauvaire), Libraire De La Societe Asiatique, Paris 1876, s. 41-42; İbn Kesîr, el-Bidaye, c. I, s. 1244-1245. 
Emevi Halifesi Abdülmelik b. Mervan, 690 yılında burada daha büyük bir inşa faaliyetine girişmiştir. Abdülmelik, Sahra kayası üzerine değerli taşlarla ve dikkat çekici desenlerle süslenmiş, önemli bir İslam mimari eseri olan Kubbetü'sSahra'yı yaptırmıştır. Kaynaklarda Abdülmelik'in böyle göz alıcı güzellikte bir yapıyı inşa ettirmedeki amacının Müslümanların buraya verdiği önemi göstermek olduğu ifade edilmektedir. Ayrıca -Hıristiyanların perspektifinden- Hıristiyanların K1yamet Kilisesi'ni mimari olarak gölgede bırakacak bir eser olmasının amaçlandığı da belirtilmektedir. ${ }^{12}$ Sahra kayası, bir kısım rivayet ve menkıbelere göre $\mathrm{Hz}$. Muhammed'in miraç gecesi üzerine basarak göklere yükseldiğine inanılan yerdir ve Mescid-i Aksa denilen tepenin tam ortasında bulunmaktadır. Mescid-i Aksa, en uzak mescit anlamına gelmekte ve ibadet alanı olarak kabul edilmektedir. Mescit ifadesi orada bulunan bir bina ile sınırlı olmayıp bahsedilen bütün tepe için kullanılmaktadır. Sahra üzerine inşa edilen Kubbetü's-Sahra ise bir ziyaret yeri olarak yapılmıştır. Mescid-i Aksa üzerinde Kubbetü's-Sahra yanında tekke, türbe ve sebil gibi başka yapılar da vardır. Kudüs, Müslümanlar tarafından Beytü'l-Makdis ve Beytü'l-Mukaddes olarak da adlandırılır. Bu isimler genel anlamda Kudüs şehrinin kutsal olarak algılandığına işaret etmektedir. Bu da Mescid-i Aksa ve Kubbetü's-Sahra'nın bulunduğu yeri içermesi sebebiyle olmuştur. ${ }^{13}$

Abbasiler döneminde Kudüs, bir diğer Müslüman devletin yönetiminde bulunmuştur. Bu dönemde Kudüs’te çeşitli depremler yaşanmış ve Mescid-i Aksa'da yer alan yapılar zarar görmüştür. Depremden zarar gören Mescid-i Aksa'daki tamir işleri için Kubbetü's-Sahra'nın süslemelerinde kullanılan altın ve gümüşler harcanmıştır. ${ }^{14} 878$ tarihinde Tolunoğulları Kudüs'ün hâkimiyetini ele geçirmiştir. Bu durum 934'e kadar sürmüştür. Bu tarihte İhşidiler yönetimi devralmıştır. 969'da ise

12 Guy Le Strange, Palestine under the moslems, University of Toronto Press, y.y. 1890, s. 90; Hitti, Islam tarihi, s. 364.

13 Hitti, İslam tarihi, s. 365; Moudjir ed-Dyn, Jerusalem, s. 121; Ebû Abdillâh Muhammed b. Ömer Fahru'd-Dîn er-Râzî, Tefsîru'l-Fahru'r-Râzî et-tefsîru'l-kebîr, mefâtîhu'l-ğayb, Daru'l Fikr, Beyrut 2005, c. VII, s. 4193.

14 Moudjir ed-Dyn, Jerusalem, s. 59. 
bölgede Fatımî idaresi başlamıştır. ${ }^{15}$ Fatımîlerden yönetimi devralan diğer Müslüman devlet Selçuklular olmuştur. Bu arada 1099 tarihinde Haçlıların Kudüs’ü ele geçirmesi ve bir Latin Krallığı kurmaları üzerine bölgedeki Müslüman yönetimi askıya alınmıştır. ${ }^{16}$ Haçlı seferi başladığında Kudüs yönetimi Fatımîlerin elinde idi. Haçlıların bölgedeki varlığı yaklaşık bir asır sürmüştür. Müslümanlar için dini ve tarihi anlamı bulunan böyle önemli bir yerin kaybedilmesinin üzüntüsü Selâhaddin Eyyûbi'nin Kudüs'ü tekrar ele geçirmesi ile sona ermiştir.

Sultan Selâhaddin, Kudüs'ü tekrar almak için harekete geçtiğinde şehirdeki Haçlıların komutası Balian'da idi. Ayrıca şehirde Patrik'in yanında Hıttin savaşından kurtulan Hospitalier tarikatından bazı şahıslar ve Tapınak Şövalyeleri de bulunuyordu. Şehrin kuşatılmasından sonra Balian eman diledi. Fidye karşıllı̆ı serbest kalmalarını sağlayan bir anlaşma yapıldı. Buna göre erkeklerden 10 dinar, kadınlardan 5 dinar ve çocuklardan 2 dinar alınacaktı. Ancak pek çok kişi fidye ödemeden şehri terk edebilmiştir. Şehirden ayrılanlar Latin kökenli Hıristiyanlar olup Haçlılardan önce yerleşmiş olan Hıristiyanlar zimmi statüsünde burada yaşamaya devam etmiştir. ${ }^{17}$ Böylece Kudüs'teki haçlıların hâkimiyeti bir asır dolmadan 27 Recep 1187 tarihinde sona ermiş ve şehir tekrar Müslüman yönetimine geçmiştir. O hafta Mescid-i Aksa'da Haçlıların yaptığı değişiklikler kaldırıldığı için ibadet edilememiştir. Zira Mescid-i Aksa üzerine Tapınak Şövalyeleri yerleşmiş, buraya kilise inşa etmişler ve Sahra kayasını da mermer ile kapatmışlardır. Bunun üzerine Mescid-i Aksa'daki resim ile heykeller kaldırılarak Sahranın üzeri yeniden açılmış ve Kubbetü'sSahra'nın tepesine asılan haç çıkarılmıştır. Bahsedilen değişiklikler yanında Nureddin'in Mescid-i Aksa'ya konulması için Halep'te yaptırdığı minber getirilerek buraya yerleştirilmiş ve Mescid-i Aksa'yı canlandırmak amacıyla vakıflar tesis edilmiştir. $^{18}$

15 Strange, Palestine, s. 98.

16 Fulcher Of Chartres; A history of the expedition to Jerusalem, (Trans. Frances Rita Ryan), University Of Minnesota, y.y. 1916, s. 99, 106.

17 İbn Kesîr, el-Bidaye, c. II, s. 929.

18 Moudjir ed-Dyn, Jerusalem, s. 72-76. 
Kudüs'ün tekrar Müslümanların eline geçtiğinin haberi Avrupa'da duyulduğunda yeni bir Haçlı seferi hazırlanmıştır. Bu sefere İngiltere kralı Arslan Yürekli Richard, Fransa kralı Philippe Auguste ve Almanya kralı Friedrich Barbarossa da katılmıştır. Sultan Selâhaddin de cihat ilan ederek bütün Müslümanları Kudüs'ü savunmaya çağırmıştır. Neticede gerçekleşen bu Haçlı seferi bir sonuca ulaşmamış ve Kudüs Müslümanların elinde kalmıştır. ${ }^{19}$ Eyyûbilerin yıkılışından sonra Kudüs, diğer bir Müslüman devlet Memlükler tarafından 1260 yılında ele geçirilmiştir. ${ }^{20}$

Yavuz Sultan Selim'in Mısır seferi sonrasında bölgeyi Memlüklerden alması üzerine Kudüs yönetimi Osmanlılara geçmiştir. Kudüs komutanı savaş olmaksızın şehrin anahtarlarını teslim etmiştir. Padişah, dört ay gibi bir süre Şam bölgesinde kalmıştır. Bu sürede kutsal yerler ile Selâhaddin Eyyûbi ve Nureddin'in kabirlerini de ziyaret etmiştir. ${ }^{21}$ Yavuz Sultan Selim, şehrin teslim alındığı tarihte değil daha sonra 31 Aralık 1516'da yanında erkânıyla birlikte Kudüs'ü ziyaret etmiştir. İkindi vakti Kudüs'e gelen padişah, şehrin dışında kurulan otağda kalmıştır. Kendisini şehir halk1 ve diğer dinlerin dini önderleri karşılamıştır. O gün Mescid-i Aksa, 12.000 kandille aydınlatılmıştır. Ertesi gün ise binlerce koyun ve deve kurban edilmiştir. Sultan Selim, şehirdeki gayr-i müslimlere hoşgörülü davranmış ve Hıristiyanlara tanıdığı hakları bildiren ve kutsal yerlerin tespit edildiği bir ferman vermiştir. Burada Hz. Ömer ve Sultan Selâhaddin dönemlerine ait emanlardaki hakların korunmaya devam edeceği ifade edilmiştir. ${ }^{22}$

Kanuni Sultan Süleyman döneminde Kudüs şehrine verilen önemin bir göstergesi olarak Mimar Sinan çeşitli inşa ve imar faaliyetleri için buraya gönderilmiştir. Kudüs'ün yeniden inşasında önemli paralar harcanmış, Kubbetü's-Sahra’nın duvar-

19 Ahmet Ağırakça, Selâhaddin Eyyûbî ve Kudüs'ün yeniden fethi, Beyan Yayınları, İstanbul 2012, s. 116, 121.

20 Cengiz Tomar, "Kudüs", DİA, İstanbul 2002, c. XXVI, s. 333.

21 Baron Joseph Von Hammer Purgstall, Büyük Osmanlı tarihi, (Çev. Mümin Çevik), MMP Basımevi, İstanbul 2010, c. II, s. 589, 590, 592.

22 Yavuz Ercan, Kudüs Ermeni patrikhanesi, Türk Tarih Kurumu Basımevi, Ankara 1988, s. 9, 12, 13, 15, 16. 
ları içeriden ve dışarıdan mavi beyaz çiniler ile döşenmiştir. Ayrıca çeşmeler, su kanalları, medrese, han ve camiler de inşa edilmiştir. Her köye bir cami yapılarak buralara imam tayin edilmiştir. ${ }^{23}$

Osmanlı devleti yaklaşık 400 yıl Kudüs yönetiminde bulunmuştur. Birinci Dünya savaşında Suriye-Filistin cephesindeki yenilgiden sonra 1917 tarihinde Kudüs’teki Osmanlı yönetimi sona ermiştir. Bölgede bu tarihten sonra kısa süre İngiliz manda yönetimi bulunmuş sonrasında 1948 'te İsrail, devlet olarak kuruluşunu ilan etmiştir. Bölgede İsrail ve Filistin arasındaki çekişmeler sürerken dünyanın diğer yerlerindeki Yahudi, Hıristiyan ve Müslümanların buraya yönelik dini algıları sebebiyle şehirle ilgili haberler gündemdeki yerini korumaktadır. Kudüs konusu çeşitli tartışmalarla birlikte uluslararası bir sorun görünümündedir.

\section{Müslüman Geleneğinde Kudüs’ün Önemi}

"Kudüs ne sıcaktır ne de soğuk, kar buraya nadir olarak yağar. Bu da cennetin özelliğidir. Ayrıca Kudüs'ten daha ihtişaml, daha iyi ve daha müreffeh bir şehir yoktur." Kudüs için bu ifadeleri sarfeden Mukaddesi şüphesiz her insan gibi sadece yaşadığı yeri övmüyordu. Bu ifadeler Müslümanların Kudüs'e atfettiği değeri göstermesi bakımından önemlidir. Çünkü bununla ne kastettiği kendisine sorulduğunda dünyayı isteyenin de ahireti isteyenin de burada aradığını bulacağını söylemiştir. ${ }^{24} \mathrm{Bu}$ da şehrin insanlar için ne ifade ettiğinin anlaşılması noktasında tarihi önemi yanında dini anlamının da bilinmesini gerekli kılmaktadır.

Müslümanların Kudüs'e yönelik dini ilgisinin kaynağı öncelikle Kur'an'da ve hadislerde geçen ifadelere dayanmaktadır. Bu anlamda Kur'an'da Kudüs'e doğrudan işaret ettiğine inanılan İsra suresi birinci ayetinden başka dolaylı olarak işaret

23 Ziya Kazıcı, Siyasi-dini-kültürel-sosyal İslam tarihi, Kayıhan Yayınları, İstanbul 1997, c. XI, s. 366.

24 Mukaddesi, İslam coğrafyası (Ahsenü't-tekâsîm), (Çev. Ahsen Batur), Selenge Yayınları, İstanbul 2015, s. 179. 
eden ayetler bulunduğu da kabul edilmektedir. ${ }^{25}$ Hadislerde geçen birtakım ifadeler de buraya gelerek ibadet etmenin önemini göstermektedir. Bunlara ilave olarak şehrin peygamber hatıralarını barındırması, önemli dini şahısların burada bir süre yaşamaları ve kabirlerinin burada bulunması da etkili olmaktadır.

Müslümanların Kudüs'e dini olarak değer vermesinin öncelikli sebebi ilk kıble olmasından kaynaklanmaktadır. Kıble, bir dine inananları diğer din mensuplarından ayırt eden bir tür kimlik göstergesi olması bakımından önemli bir semboldür. Bütün Peygamberlerin kıblesinin Kudüs mü yoksa Kâbe mi olduğuna dair net bir bilgi olmayıp bu konuda çeşitli ihtilaflar bulunmaktadır. Peygamberlerin kıble konusunda birbirlerine muhalefet etmeyeceği ayrıca geçmiş kitaplarda son peygamberin özelliklerinden birinin de kıbleyi Kâbe'ye çevirmek olduğu ifade edilmektedir. ${ }^{26}$ Böylece kıblenin bütün peygamberler için aynı olduğu belirtilirken kıblenin hangisi olduğunda görüşler farklılaşmaktadır. Bazı kaynaklarda bütün peygamberlerin kıblesinin ilk mescit hadisine dayanılarak Kâbe olduğu kabul edilmektedir. ${ }^{27}$

Bununla birlikte Hz. Muhammed, her iki yöne doğru da ibadet etmiştir. Hz. Muhammed'in Mekke döneminde kıblesinin neresi olduğu konusunda çeşitli tartışmalar mevcuttur. ${ }^{28}$ Mekke döneminde Kâbe'yi kıble kabul eden rivayetler yanında Kudüs'ün kıble olduğu da iddia edilmekte, Be'ra hadisi denilen bir rivayette bahsi geçen olayın Müslümanların Mekke döneminde namazlarda Kudüs'e yöneldiklerine işaret ettiği kabul edilmektedir. ${ }^{29}$ Medine'de ise kıblenin tahvil edilmesini emreden

25 Abdullah el-Khatip, “Kur'an'da Kudüs”, (Çev. Ramazan Işık), Fırat Üniversitesi İlahiyat Fakültesi Dergisi, Elazı ğ, 2004, Cilt: IX, Sayı: 1, s. 122.

26 Elmalılı Hamdi Yazır, Hak dini Kur'an dili, (Sad. İsmail Karaçam, Emin Işık, Nusrettin Bolelli ve Abdullah Yücel), Azim Yayınları, İstanbul 2014, c. I, s. 537.

27 İbn Kesîr, el-Bidaye, c. I, s. 562; Muhammed b. Sa'd b. Menî el-Hâşimî el-Basrî, Kitâbü't-tabakâti'l-kebîr, Kolektif, Siyer Yayınları, İstanbul 2014, c. I, s. 231.

28 Yavuz Ünal, "Hadis verilerine göre Hz. Peygamber'in ilk kıblesi: Beyt-i Makdis”, Ondokuz Mayls Üniversitesi Illahiyat Fakültesi Dergisi, Samsun 2001, Sayı: 12-13, s. 192.

29 İbn Kesîr, el-Bidaye, c. I, s. 513; Müşrik olan kavmimizin hacılarıyla beraber çıktık. Biz ve imamımız namaz kıldık. Be'ra b. Ma'rur da bizimle beraberdi. Yola çıkıp Medine'den ayrıldığımızda Be'ra bize dedi ki: Ey cemaat ben bir reye varmış bulunuyorum. Bu konuda bana katılıp katılmayacağınızı da bilmiyorum. Biz, nedir, dedik. Be'ra: Vallahi şu binayı yani Kâbe'yi arkama almayacağım. Ona doğru namaz kılacağım, dedi. Ona Vallahi 
aye $^{30}$ gelinceye kadar yaklaşık 16, 17 ay Kudüs'e yönelerek namaz kılındığı bildirilmektedir. ${ }^{31}$ Kıblenin değişmesinden sonra Kudüs, Müslümanlar için önemini kaybetmemiş üçüncü önemli mescit olarak değerini korumaya devam etmiştir. Çünkü Kudüs'ün kutsallığı ile ilgili tek husus kıble olması değildir, şehir hakkındaki diğer rivayetler buranın önemini korumasını sağlamıştır.

Müslümanların Kudüs'e atfettiği değerin diğer sebebi miraç hadisesinde aldığı konumdan kaynaklanmaktadır. Miraç; yukarı çıkmak, yükselmek anlamındaki uruc kökünden türetilmiş olup yukarı çıkma vasıtası/merdiven anlamına gelmektedir. Kutsala doğru yapılan yolculuk olarak anlaşılmaktadır. Burada ilahi âlemlere yükselen dostlarla görüşmelerin yaşandığına, cennet ve cehennemde bulunan ruhların müşahede edildiğine, çeşitli hikmet ve sırlara vakıf olunduğuna inanılmaktadır. ${ }^{32}$ İslam geleneğinde Hz. İsa, Hz. İdris, Hz. İlyas ve Hızır'ın cennete yükseldiğine inanılmakta ve yükselişlerinin Kudüs’ten gerçekleştiği kabul edilmektedir. ${ }^{33}$

Bu bağlamda Hz. Muhammed'in miraç hadisesinin de Kudüs'teki Mescid-i Aksa'dan gerçekleştiği ifade edilmektedir. Nitekim İsra suresinin birinci ayetinde bu

peygamberin Şam'a doğru namaz kıldığından başka bir haber almadık. Biz ona muhalefet etmeyi istemiyoruz dedik. Be'ra, Ben ona doğru namaz kılacağım, dedi. Biz, fakat biz bunu yapmayacağız, dedik. Namaz vakti geldiğinde biz Şam'a doğru namaz kılıyorduk. O ise Kâbe'ye doğru namaz kılıyordu. Nihayet Mekke'ye geldik. Onu yaptığından ötürü ayıplıyorduk. O ise bir türlü kabul etmiyor öyle kalmayı istiyordu. Mekke'ye ulaştığımızda bana dedi ki: Ey kardeşimin oğlu Rasulullah'a gidelim ve ondan bu durumu soralım. Çünkü içime bir şüphe düştü. Buna muhalefet ettiğinizi görüyorum. İkimiz birlikte Rasulullah'a gittik. Be'ra şöyle dedi: Ey Allah'ın Rasulü yola çıktım. Allah beni İslam'a hidayet etti. Ben bu binayı yani Kâbe'yi arkama almamayı hak gördüm. Ona doğru namaz kıldım. Arkadaşlarım ise bu konuda bana muhalefet ettiler. İçime bir şüphe düştü. Ya Rasulullah bunu nasıl görürsün? Bunun üzerine Allah Rasulü: Sen bir kıble üzerindeydin. Onda sabretseydin ya, dedi. Bundan sonra Be'ra Rasulullah'ın kıblesine döndü ve bizimle beraber Şam'a doğru namaz kıldı.

30 Bakara 2/144.

31 Ebû Abdillah Muhammed b. İsmail el-Buhârî, el-Câmiu's-sahîh, Daru'l-Beşairu'l-İslamiyye, Beyrut 2011, Kitâbu's-salât, 31.

32 Şinasi Gündüz, Yavuz Ünal ve Ekrem Sarıkçığlu, Dinlerde yükseliş motifleri ve İslâm'da miraç, Vadi Yayınları, İstanbul 2016, s. 19, 39, 40.

33 Yazır, Hak dini Kur'an dili, c. II, s. 480-481; İbn Kesîr, Hadislerle Kur'an-ı Kerim tefsiri, (Çev. Bekir Karlığa ve Bedreddin Çetiner), Çağrı Yayınları, İstanbul 2005, c. X, s. 5155. 
konudan bahsedildiğine inanılmaktadır. "Geceleyin kulunu Mescid-i Haram'dan çevresini bereketli kıldı̆̆ımız Mescid-i Aksa'ya yürüten Allah eksikliklerden uzaktır. O’na ayetlerimizden bazılarını gösterelim diye böyle yaptık. Gerçekten işitendir, görendir." Konunun anlaşılması amacıyla yukarıdaki ayette yer alan hususlardan Mescid-i Aksa'nın neresi olduğu, çevresi bereketli kılınmış yer ile ne kastedildiği ve gösterilen birtakım ayetlerin neler olduğunun bilinmesi önemlidir. Ayette ifade edilen Mescid-i Aksa'nın, bu konuda birtakım tartışmalar bulunmakla beraber genel anlayışa göre Kudüs'te olduğu kabul edilmektedir. Çevresinin bereketli kılınması ile kastedilenin buradaki meyve ve çiçeklerin bolluğu olduğu ayrıca Kudüs'ün peygamberlerin durağı ve meleklerin iniş yeri olması sebebiyle söylendiği belirtilmektedir. ${ }^{34}$ Bahsedilen diğer konu -Allah'ın ayetlerinden bir kısmının gösterilmesi- ise $\mathrm{Hz}$. Muhammed'e cennet-cehennem örneklerinin gösterilmesi, peygamberler ile buluşması, meleklerin gösterilmesi, gök katlarına çıkarılması, Kudüs'e götürülmesi ve iki aylık mesafeyi bir anda gitmesi gibi farklı şekillerde anlaşılmıştır. ${ }^{35}$

Öte taraftan Hz. Muhammed'in Kudüs'e kadar gitme süreci İsra, orada yaşadıkları ile göklere yapılan yolculuğu ise Miraç olarak anılmaktadır. Bu arada miraca çıkarılmadan evvel neden Mekke'den Kudüs'e getirildiği konusunda farklı açıklamalar bulunmaktadır. Bir görüşe göre Mescid-i Aksa, yeryüzünün göğe en yakın yeri olması sebebiyle göklere yapılan yolculuk buradan başlamıştır. Diğer bir görüşte meleklerin inip çıktığı gök kapısının burada olması sebebiyle doğrudan göklere çıkarılması için getirildiği ifade edilmektedir. Bir başka görüşe göre ise pek çok peygamberin bulunduğu ve ibadet ettiği bu yerin $\mathrm{Hz}$. Muhammed'in ziyareti ile şeref kazanması amacıyla miraç yolculuğu buradan gerçekleşmiştir. Hz. Muhammed, İsra hadisesini anlatırken yolculuk süresinde bazı yerlerde durarak namaz kıldığını söylemiştir. İlk olarak Taybe'ye (Medine) gelmiş, Cebrail burasının hicret edeceği yer olduğunu söylemiştir. Daha sonra Tur-i Sina'da durmuştur. Cebrail, burada Hz. Musa'nın Allah ile konuştuğunu bildirmiştir. Hz. Muhammed, son olarak Beytü’l-

34 Râzî, Mefâtîhu'l-ğayb, c. VII, s. 4193.

35 İbn Kesîr, Hadislerle Kur'an-ı Kerim tefsiri, c. IX, s. 4660. 
Lahm'de durmuş ve buranın Hz. İsa'nın doğduğu yer olduğunu öğrenmiştir. Ayrıca Hz. Peygamber, Kudüs'teki Beytü'l Makdis'e ulaştığında orada diğer peygamberlerle buluştuğunu, onlara imam olup namaz kıldırdığını da haber vermiştir. ${ }^{36}$

Diğer taraftan Hz. Ömer'in fethi sırasında anlatılanlara bakılarak mabedin miraç gecesi harabe halde olduğu ve Hz. Muhammed'in Beytü'l Makdis'e girmesinin mümkün olamayacağı iddia edilmektedir. Bununla beraber Hz. Muhammed'in miraç hadisesini kavmine anlattığından bahseden rivayetlerde orayı bilen kimselerin kendisine birtakım sorular sorduğu anlatılmaktadır. Hz. Muhammed'in o gece ayrınt1lı şekilde dikkat etmediği için tam olarak hatırlayamadığı, sonra gözlerinin önünde görür gibi olduğu ve sorulara (kapıları, dağa uzaklığının ne kadar olduğu gibi) buna bakarak cevap verdiği rivayet edilmektedir. ${ }^{37} \mathrm{O}$ halde buradaki rivayette $\mathrm{Hz}$. Muhammed, hangi mescidin kapılarından bahsetmiştir?

Yukarıda ifade edildiği üzere Mescid-i Aksa ismi şehrin surlarla çevrili bölgesinin tamamı için kullanılır. Süleyman Mabedi ise bu alanın ortasında inşa edilmiştir. Hz. Muhammed surla çevrili alanın kapılarından bahsedilen kısma girmiş olmalıdır. Kaldı ki ayette Mescid-i Aksa ifadesi geçerken müşriklerin Hz. Muhammed'den bilgi isteklerine dair rivayetlerde Beytü'1 Mukaddes ifadesi kullanılmaktadır. Anlaşılan o ki kastedilen husus taraflarca bilinmektedir. Görüldügü gibi tarifi istenilen yer, Süleyman Mabedi değil Kudüs'te mevcut bulunan kısımlardır. ${ }^{38}$

36 İbn Kesîr, Hadislerle Kur'an-ı Kerim tefsiri, c. IX, s. 4611, 4613, 4663.

37 Buhârî, Kitabu't-tefsir, 17.

38 Bak. İbn Kesîr, Hadislerle Kur'an-ı Kerim tefsiri, c. IX, s. 4653; Bu konudaki bir rivayete göre Hz. Muhammed, Bizans Kayser'ine İslam'a davet mektubu göndermiştir. Kayser, görüşlerini almak üzere Ebu Süfyan'ın da içinde bulunduğu Şam'daki Mekkeli tüccarları çağırmıştır. Ebu Süfyan, burada Hz. Muhammed'i küçük düşürmek için miraç hadisesini anlatmış ve onun bir gece içinde Kudüs’teki Mescid-i Aksa’ya gittiğinden bahsetmiştir. Kudüs Patriği, o geceyi bildiğini söylemiş, o gece mescidin kapılarından birini kapatamadıklarını, sabah geldiklerinde mescidin bir köşesinde bulunan taşın delindiğini ve bir hayvanın buraya bağlandığını, bunun izini gördüğünü ve arkadaşlarına bu kapının o gece bir peygamber için açıldığını düşündüğünü söylemiştir. 
Kur'an'da Kudüs çevresinin kutsallığından ${ }^{39}$ bahsedilmesi insanların buraya gelip dua ve ibadet etmelerinin öncelikli sebebidir. Bununla beraber Kudüs'e gelerek ibadet etmenin önemini gösteren çeşitli hadisler de bulunmaktadır. Bu konuda ilk olarak karşılaşılan şu hadistir: "Ü̧̧ mescit yani Kâbe, Medine'deki benim mescidim ve Mescid-i Aksa (ibadet için) hariç yolculuk etmek doğru değildir." ${ }^{40}$ Bu rivayette Kudüs'ü ibadet amaçlı ziyaret etmenin öneminden bahsedilirken diğer bir hadiste burada kılınan namazlardan fazla sevap umulacağı anlaşılmaktadır. "Kişinin Mescidi Aksa'da kıldiğı namazı elli bin namaza eşittir, benim mescidimde kıldı̆̆ namazı elli bin namaza eşittir, Mescid-i Haram'da kıldı̆̆ı namazl yüz bin namaza eşittir." 41 Bahsi geçen rivayetlerde Kudüs’teki mescit, Kâbe ve Medine'deki mescitle birlikte anılmaktadır. "Yeryüzünde inşa edilen ilk mescidin hangi mescit olduğunu Peygambere sordum. Mekke'deki Mescid-i Haram'dır, dedi. Ondan sonra hangisi inşa edildi, diye sordum. Mescid-i Aksa dedi. Bu ikisi arasında kaç yll vardır diye sordum, kırk yıl dedi." ${ }^{42}$ Yukarıda geçen bu rivayette ise üç mescit arasında bir sıralama yapılmaktadır. Ancak bu, bir diğerinin değerini eksiltmek olarak anlaşılmamıştır. Nitekim aşağıdaki rivayet Kudüs’teki mescidi ziyaretin Müslümanlar için ne kadar önemli olduğunu göstermektedir.

“Süleyman Mescid-i Aksa'yl yaptı̆ğıda Rabbinden ü̧̧ şey istemiştir. Rabbi ona ikisini verdi. Ben üçüncüsünü de vermiş olmasını ümit ediyorum. Kendisine, kendi hükmüne denk gelecek hüküm vermesini istedi. Rabbi bu istediğini verdi. Kendisinden sonra hiç kimsenin ulaşamayacağı bir saltanat vermesini istedi. Bu istediğini de verdi. Bir de kim bu mescitte namaz kllmak amacuyla evinden çıkarsa annesinden doğmuş gibi günahlarından arınmasını istedi. Biz bu isteğini de Allah'ın ona vermiş olmasını ümit ediyoruz. "43

39 İsra $17 / 1$.

40 Ebû Abdillah Muhammed b. Yezid el-Kazvînî İbn Mâce, es-Sünen, (Thk. Muhammed Fuad Abdulbaki), Dâr-u İhyai'l-Kütübi'l-Arabiyye, y.y. ty., Kitabu ikameti's-salati ve'ssünneti fiha, 196.

41 İbn Mâce, Kitabu ikameti's-salati ve's-sünneti fiha, 198.

42 Buhârî, Kitabu'l enbiya, 10.

43 İbn Mâce, Kitabu ikameti's-salati ve's-sünneti fiha, 196. 
Meymune hadisi olarak da bilinen rivayette de aynı durum görülmektedir. $\mathrm{Bu}$ rivayetin kıblenin Kâbe yönüne değiştirilmesinden sonra Kudüs'ün durumunu öğrenmek amacıyla sorulması üzerine açıklandığı düşünülmektedir. ${ }^{44}$ Söz konusu rivayet kıble Kâbe yönüne değişse dahi Kudüs'ün önemini kaybetmediğini işaret etmektedir.

“Hz. Meymune: Ben bir gün Rasulullah'a bize Beyt-i Makdis hakkinda fetva ver, dedim. Rasulullah, orası mahşer yeridir. Oraya ulaşıp namaz kılınız; çünkü orada kllınan namaz başka yerde kllınan bin namaz gibidir, dedi. Ben, eğer oraya gitmeye gü̈ yetiremezsem ne yapayım, dedim. Sen ona zeytinyağı hediye et ki onunla aydinlatılsin, kim bunu yaparsa oraya gitmis gibidir, dedi." ${ }^{45}$

Son olarak Kudüs'ün dünyanın sonunda meydana gelecek hadiselerden bazıları ile ilişkilendirildiği görülmektedir. Bunlara göre Mehdi, bu şehre gelecek, k1yamet alametlerinden bir kısmı burada gerçekleşecek ve yeniden dirilişten sonra insanlar burada toplanacaktır. Kıyamet alametleri ve Mehdi konusunda çeşitli hadislerde yer alan rivayetler delil olarak alınırken, mahşer yerinin Kudüs olması hususunda ise bazı ayetlerin referans olarak kullanıldığı görülmektedir. Bu konuda tefsirlerde Kaf suresinde "Çağrıcının yakın bir yerden sesleneceği gün o sese kulak ver ${ }^{346}$ ayetindeki yakn yer ile kastedilenin Kudüs olduğu belirtilmektedir. ${ }^{47}$ Mahşer yerinin Kudüs olması hakkında Naziat suresindeki "Birdenbire kendilerini toprağın üstünde buluverirler" ${ }^{\text {"48 }}$ ayetinde geçen sahire kelimesinin açıklamalarında da benzer bilgilere rastlanmaktadır. Buna göre sahire'nin beyaz, dümdüz yer anlamına geldiği bu mekânın da Kudüs’teki Sahra kayası olduğu ifade edilmektedir. ${ }^{49}$

44 Ebû Abdullah Muhammed b. Yezid el-Kazvînî İbn Mâce, Sünen-i İbn Mâce tercemesi ve şerhi, (Çev. Haydar Hatipoğlu), Kahraman Yayınları, İstanbul 2012, c. IV, s. 223.

45 İbn Mâce, Kitabu ikameti's-salati ve's-sünneti fiha, 196.

46 Kaf 50/41.

47 İbn Kesîr, Hadislerle Kur'an-ı Kerim tefsiri, c. XIII, s. 7466.

48 Naziat 79/14.

49 İbn Kesîr, Hadislerle Kur'an-ı Kerim tefsiri, c. XV, s. 8270; Râzî, Mefâtîhu'l-ğayb, c. XI, s. 36. 


\section{Sonuç}

Yukarıda ifade edildiği üzere Müslümanların Kudüs ile derin tarihi ve dini bağları bulunmaktadır ki bu husus şehrin herhangi bir yerden daha fazla anlam ifade etmesine sebep olmaktadır. Kutsallığının gerekçeleri olarak sayılan hususlar her ne kadar zaman zaman tartışma konusu yapılsa da Kudüs, Müslümanların kutsalları arasında yer almaktadır. Ayrıca buraya atfedilen değer dolayısıyla Kudüs'te gerçekleşen hadiseler de Şiisinden Sünnisine kadar bütün dünya Müslümanlarını etkilemektedir. Kudüs'ün bir süre Müslümanlara kıble olması ve Hz. Muhammed'in İsra gecesindeki ziyareti, bugün başka bir dinin mensuplarının elinde olmasını kabul etmeyi zorlaştırmaktadır. Bu arada şunu da belirtmek gerekmektedir ki burada ibadet etmeye ve buradaki ibadetin faziletlerine yönelik birtakım rivayetler, Müslümanların nezdinde şehrin kutsallığının salt tarihsel hadiselerle sınırlandırılmadığını gösterdiği gibi aynı zamanda Müslümanların ilgilerinin azalmaksızın bugün de devam etmesinin en önemli sebepleri arasında yer almaktadır. Dolayısıyla şehir, geçmişten bugüne Müslümanlar için ifade ettiği anlamı korumaktadır.

\section{Kaynakça}

Ağırakça, Ahmet, Selâhaddin Eyyûbî ve Kudüs'ün yeniden fethi, Beyan Yayınları, İstanbul 2012. Armstrong, Karen, Jerusalem one city three faith, Ballantine Books, United States Of America 1996.

Buhârî, Ebû Abdillah Muhammed b. İsmail, el-Câmiu's-sahîh, Daru'l-Beşairi'l-İslamiyye, Beyrut 2011.

el-Khatip, Abdullah, “Kur'an'da Kudüs”, Fırat Üniversitesi Illahiyat Fakültesi Dergisi, (Çev. Ramazan Işık), Elazı̆̆ 2004, Cilt: IX, Sayı: 1, s. 23-32.

Ercan, Yavuz, Kudüs Ermeni patrikhanesi, Türk Tarih Kurumu Basımevi, Ankara 1988.

Fayda, Mustafa, Hz. Ömer zamanında gayr-ı müslimler, Marmara İlahiyat Fakültesi Yayınları, İstanbul 1989.

Fulcher Of Chartres, A history of the expedition to Jerusalem, (Trans. Frances Rita Ryan), University Of Minnesota, y.y. 1916.

Günaltay, Şemsettin, Yakın şark, Suriye ve Filistin III, Türk Tarih Kurumu Yayınları, Ankara 1947. 
Gündüz, Şinasi, Ünal, Yavuz ve Sarıcçığlu, Ekrem, Dinlerde yükseliş motifleri ve İslâm 'da miraç, Vadi Yayınları, İstanbul 2016.

Harman, Ömer Faruk, “Kudüs”, DİA, İstanbul 2002, c. XXVI, ss. 323-327.

Hitti, Philip Khuri, Siyasal ve kültürel İslam tarihi, (Çev. Salih Tuğ), İFAV, İstanbul 2011.

İbn Kesîr, Ebü'l-Fidâ İmâdüddin İsmâil b. Şihâbiddîn Ömer, el-Bidaye ve'n-nihaye, Beytü'l Efkârî'l Devliyye, Amman 2004.

İbn Kesîr, Hadislerle Kur'an-ı kerim tefsiri, (Çev. Bekir Karlığa ve Bedreddin Çetiner), Çağrı Yayınları, İstanbul 2005.

İbn Mâce, Ebû Abdillah Muhammed b. Yezid el-Kazvînî, es-Sünen, Daru İbn-i Heysem, Kahire 2005.

; Sünen-i İbn Mâce tercemesi ve şerhi, (Çev. Haydar Hatipoğlu), Kahraman Yayınları, İstanbul 2012.

İbn Sa'd, Muhammed b. Sa'd b. Menî el-Hâşimî el-Basrî, Kitâbü 't-tabakâti'l-kebîr, Kolektif, Siyer Yayınları, İstanbul 2014.

Josephus, Flavius, The works of Josephus, (Trans. William Whiston), Hendrickson, America 1999.

Kazıcı, Ziya, Siyasi-dini-kültürel-sosyal İslam tarihi, Kayıhan Yayınları, İstanbul 1997.

Kitabı mukaddes, Kitabı Mukaddes Şirketi Yayınları, İstanbul 2005.

Kur'an'ı Kerim meâli, (Çev. Halil Altuntaş ve Muzaffer Şahin), Diyanet İşleri Başkanlığı Yayınları, Ankara 2006.

Moudjir ed-Dyn, Histoire de Jerusalem et d'Hebron depuis Abraham jusqu'a a la fin du xv siecle de j.c, (Trans. Henri Sauvaire), Libraire De La Societe Asiatique, Paris 1876.

Mukaddesi, İslam coğrafyası (Ahsenü 't-tekâsîm), (Çev. Ahsen Batur), Selenge Yay., İstanbul 2015.

Hammer, Baron Joseph Von Purgstall, Büyük Osmanlı tarihi, (Çev. Mümin Çevik), MMP Basımevi, İstanbul 2010.

Râzî, Ebû Abdillâh Muhammed b. Ömer Fahru'd-Dîn, Tefsîru'l-Fahru'r-Râzî̀: et-tefsîru'l-kebîr, mefâtîhu'l-ğayb, Daru'l-Fikr, Beyrut 2005.

Strange, Guy Le, Palestine under the moslems, y.y., University of Toronto Press, 1890.

Tomar, Cengiz, "Kudüs”, DİA, İstanbul 2002, c. XXVI, ss. 332-334.

Ünal, Yavuz, "Hadis verilerine göre Hz. Peygamber'in ilk kıblesi: Beyt-i Makdis”, Ondokuz Mayıs Üniversitesi Illahiyat Fakültesi Dergisi, Samsun 2001, Sayı: 12-13, ss. 189-211.

Yazır, Elmalılı Hamdi, Hak dini Kur'an dili, (Sad. İsmail Karaçam, Emin Işık, Nusrettin Bolelli ve Abdullah Yücel), Azim Yayınları, İstanbul 2014.

Yemeni, Muhammed, Feza'ilü'l-Mekke ve'l-Medine ve'l-Kudüs, ty, y.y. 